\title{
Pharmacodynamic differences of afobazole and its active metabolite
}

\section{Sergey Seredenin, Milada Yarkova}

\section{Zakusov Institute of Pharmacology, Russia}

Afobazole (5-etoxy-2[2-(morpholino)ethylthio] benzimidazole dihydrochloride) was developed as an anxiolytic at the Zakusov Institute of Pharmacology (Moscow). Among 17 metabolites of afobazole, the active compound (2-[2-(3oxomorpholine-4-yl)-ethylthio]-5-ethoxy benzimidazole hydrochloride) M-11 was found.

Afobazole - multitargeting drug, interacts with $\mathrm{MT}_{1}(\mathrm{Ki}=1,6 \mathrm{E}-5 \mathrm{M})$, Quinone Reductase 2 (NQO2) (Ki=9,7E-7 M), sigma 1 receptors $(\mathrm{Ki}=5,9 \mathrm{E}-6 \mathrm{M})$ and $\mathrm{MAO}-\mathrm{A}(\mathrm{Ki}=3,6 \mathrm{E}-6 \mathrm{M})$.

$\mathrm{M}-11$, in contrast to afobazole, interacts only with Quinone Reductase 2 (NQO2) (Ki=3,9E-7 M).

Thus, a comparative analysis of the pharmacological effects of afobazole and M-11 can be a useful tool for determining the contribution of the NQO2 to the pharmacological activity.

It was established previously that the stress-induced benzodiazepine binding decrease could be considered as a marker of anxiety level and of anxiolytic effect.

The purpose of this work was a comparative study of afobazole and M-11 effects on the level of benzodiazepine receptions as a marker of anxiolytic action.

Methods: Open field (OF), Exposure to a predator (EP), Radioligand binding assay. The experiments were carried out on inbred $\mathrm{C} 57 \mathrm{Bl} / 6$ and $\mathrm{BALB} / \mathrm{c}$ with opposite OF behavior.

Results: The level of specific $\left[\mathrm{N}\right.$-methyl $\left.{ }^{3} \mathrm{H}\right]$-flunitrazepam binding with $\mathrm{P} 1+\mathrm{P} 2$ membrane fraction of $\mathrm{C} 57 \mathrm{Bl} / 6$ and $\mathrm{Balb} / \mathrm{c}$ mice brain tissue was studied after OF and EP. After OF decrease of benzodiazepine reception was registered in $\mathrm{Balb} / \mathrm{c}$ mice only. EP test provoked the decrease of labeled ligand binding both in $\mathrm{Balb} / \mathrm{c}$ and $\mathrm{C} 57 \mathrm{Bl} / 6$ mice.

Afobazole restored anxiety-induced decrease of $\left[\mathrm{N}\right.$-methyl $\left.-{ }^{3} \mathrm{H}\right]$-flunitrazepam binding in all used stress irrespective of mice strain.

Active metabolite M-11 demonstrated the anxiolytic effect in the OF test and prevents the anxiety -induced radioligand binding decrease only in Balb/c mice. Pretreatment with M-11 did not restore of the anxiety-induced behavior and benzodiazepine binding in $\mathrm{Balb} / \mathrm{c}$ and $\mathrm{C} 57 \mathrm{Bl} / 6$ mice after EP.

Conclusion:

1. Being ligand of MT1, NQO2, sigma 1 receptors and MAO A regulatory site afobazole has more pronounced anxiolytic activity than M-11 which interacts with NQO2 only.

2. NQO2 inhibition contributes to anxiolytic effect of afobazole. 